\title{
War against famine, for nutrition
}

In Somalia, the world is fighting an unprecedented war in the name of basic nutrition. In the United States, the government has gone overboard on the matter of nutrition and health.

THE world embarked on a perilous military venture last week when the United Nations resolved to invade Somalia for humanitarian purposes. An estimated two million Somalis, their stomachs bloated, their ribs showing, are said to be in danger of imminent starvation because warring clan lords are stealing food from relief agencies.

Faced with the sight of dying women and children, soldiers from as many as 11 nations, led by the US military, will march into Somalia, a desolate, government-less country, to distribute food--nothing more, nothing less. The White House says the purpose of the UN mission is "not to establish a new government or resolve the decades-long conflict there or to set up a protectorate, or anything like that." Nor is the UN going in to protect broad world interests, as was the case with oil in the Gulf War. Somalia has nothing of strategic significance. It does not even have proper roads.

\section{No high technology}

Thus, in a late twentieth century world whose military actions have depended on increasingly sophisticated technology, soldiers are being deployed with no need for 'smart' weapons. The sciences of physics, metallurgy and remote sensing apparently have no role to play in a theatre in which the opponents are armed with conventional guns, grenades and potholes. Furthermore, if we are to believe that this UN action is undertaken only to assure the distribution of bags of rice and wheat already in Somali warehouses, there is no call for agricultural science here. There is no green revolution in the cards, just a short-range (and short-sighted) plan to defeat imminent death by distributing bowls of rice. Nutrition at its most basic. In terms of science, this is a throwback to another era. And it is military intervention without a meaningful plan.

There is no little irony then that the day before announcing the despatch of American soldiers to Somalia, US President George Bush made headlines on another (equally low-technology) nutritional front. The president stepped into a bitter battle between the Secretaries of Health and Human Services (HHS) and Agriculture over nutritional labels on food. Conflict over what to say about fat was particularly intense. (The Somalis have no dietary fat; Americans too much.)

The HHS secretary flavoured a label that puts the content of food into the context of a daily 'average' diet of 2,000 calories, restricted to 65 grams of fat. The agriculture secretary (and the meat and dairy interests his department regulates) wanted to limit labels to food content, with no information about percentages of daily diet. In the event, 'context' and HHS carried the day. Next month, new food labelling regulations running to 4,000 pages will become law. The bone thrown to agriculture (thank heaven) is an agreement that food labels will not be required on restaurant menus, leaving people to dine in peace.

\section{Dietary guidelines}

The label, which will appear in standard format on virtually all foods sold in the United States, is predicated on the hopeful presumption that enough is known about nutrition to establish valid dietary guidelines for a large and diverse population. The premise is open to challenge (as this journal has said before). But even if that were not the case, one look at the new labels is enough to discourage even the most ardent fitness buffs. Standard serving sizes are established as $1 / 2$ cup or $114 \mathrm{~g}$. In a sample label, then, total fat is listed as $13 \mathrm{~g}$ or 20 per cent of the standard daily diet of 2000 calories. In the next line, saturated fat is reported to be $5 \mathrm{~g}$ or 25 percent of the total diet. The quantities and percentages of cholesterol, sodium, sugars and dietary fiber are also calculated, leaving the consumer in need of a mainframe computer to translate it all into practical terms. Indeed, the information is all but incomprehensible.

Hunger, satiety and longevity are basic drives fuelling the course of politics in two very different but significant ways. Perhaps it is inevitable that the UN decided to authorize military intervention in Somalia. There is a moral imperative to prevent millions of innocent people from dying needlessly. But it is not as simple as Bush stated when he said that famine in Somalia is a tragedy "we could do something about". Soldiers will lose their lives; the Somalis will not really be helped without a UN commitment to the long run, but the prospect of Western soldiers in Somalia for years is evidence only that the way out of one quagmire (imminent starvation) is to march into another.

On the US domestic front, the plan to put incomprehensible nutritional information on more that 300,000 foods (a bureaucratic nightmare that could well spill over to the European Communities) raises the spectre of a different quagmire. In both cases, last week's political actions are based on compassion and good intentions, but they are not smart. 